\title{
INTRACRANIAL HEMANGIOPERICYTOMA: A CASE REPORT
}

\author{
INTRAKRANYAL HEMANJIOPERISITTOMA: BIR OLGU SUNUMU
}

\author{
Neşe KESER*, Erhan ÇELIKOĞLU*, Merih İŞ*, İbrahim TUTKAN*, İmam Hüseyin AYDIN*, \\ Ahmet Ŭgur KEVENK*, Adnan SOMAY**
}

\begin{abstract}
Meningeal hemangiopericytoma (HPC) originating from pericytes is a highly vascularised and a rare mesenchimal tumor that constitutes $\% 0.4$ of all primary central nervous system tumors. These tumors share common arachnoid location with benign meningioma and mimic meningiomas in clinical and radiographic presentation. Because of the aggressive nature of the central nervous system HPs with high recurrence and distal metastasis rates the first line treatment is total resection with close follow ups postoperatively. In this report we tried to analyse the differentiation of hematoma and recurrence and evaluated the role of radiotherapy in light of the current literature.
\end{abstract}

Keywords: hematoma, intracranial hemangiopericytoma, treatment

\section{ÖZET}

Meningial hemanjioperisitoma (HP) primer merkezi sinir sistemi tümörlerinin $0,4 \%$ ünü oluşturan nadir ve oldukça vasküler bir mezenkimal tümördür. Hemanjioperisitomalar benign meningiomlarla ortak araknoid lokasyonlari kullanırlar, klinik ve radyolojik olarak onları taklit ederler. Perisitlerden kaynaklanan bu tümörlerde total rezeksiyon ilk tedavi seçeneği olup merkezi sinir sistemi HP larının agresif biolojisi nedeni ile rekurrens ve uzak metastaz ihtimali de göz önünde bulundurularak ameliyat sonrası yakın takibi çok önem taşır. Bu yazıda HP larda postop dönemde ortaya çıkabilen komplikasyonlardan olan rekurrens ve hematomun ayırt ettirici özelliklerinin vurgulanması ve radyoterapinin yeri konusunda son literatür bilgilerinin gözden geçirilmesi amaçlanmıştır.

Anahtar sözcükler: hematom, intrakranyal hemanjioperisitoma, tedavi

\section{INTRODUCTION}

Meningeal hemangiopericytoma (HPC) is a rare and malignant vascularized mesenchymal tumor that makes up $0.4 \%$ of all primary central nervous system (CNS) tumors. For these tumors, which originate from pericytes, the first treatment choice is total resection. Moreover, close postoperative follow-up is very important because of the high recurrence rates and likelihood of distal metastasis due to the aggressive nature of central nervous system HPCs. In this report, we differentiate from hematoma and HPC recurrence and evaluate the role of radiotherapy (RT) in light of the current literature.

A patient presented with an HPC, a rare intracranial tumor. Alternative treatment methods and the criteria for the differentiation of postoperative complications had to be considered.

\section{CASE PRESENTATION}

A 45-year-old man came to our outpatient clinic with the complaint of cephalgia and left arm weakness. He had had cephalgia for the past year and the additional complaint of left arm weakness had arisen 1 month previously.

In his neurological exam, paresia was found in $1 / 5$ of the left arm (ipsilateral). In his supratentorial cranial magnetic resonance (MR) slices, there was an extraaxial lesion that was $37 \times 47 \times 52 \mathrm{~mm}$ in size and located superiorly in the region of the left temporal bone (Figure-1a; 1b; 1c; 1d).

\footnotetext{
Date received/Dergiye geldiği tarih: 08.03.2014 - Dergiye kabul edildiği tarih: 30.04.2014

Fatih Sultan Mehmet Eğitim ve Araştırma Hastanesi, Beyin Cerrahisi Bölümü* ve Patoloji Bölümü**, İstanbul

(İletişim kurulacak yazar: nskeser@gmail.com)
} 
Figure 1a. Preop (TM) T1 axial MR

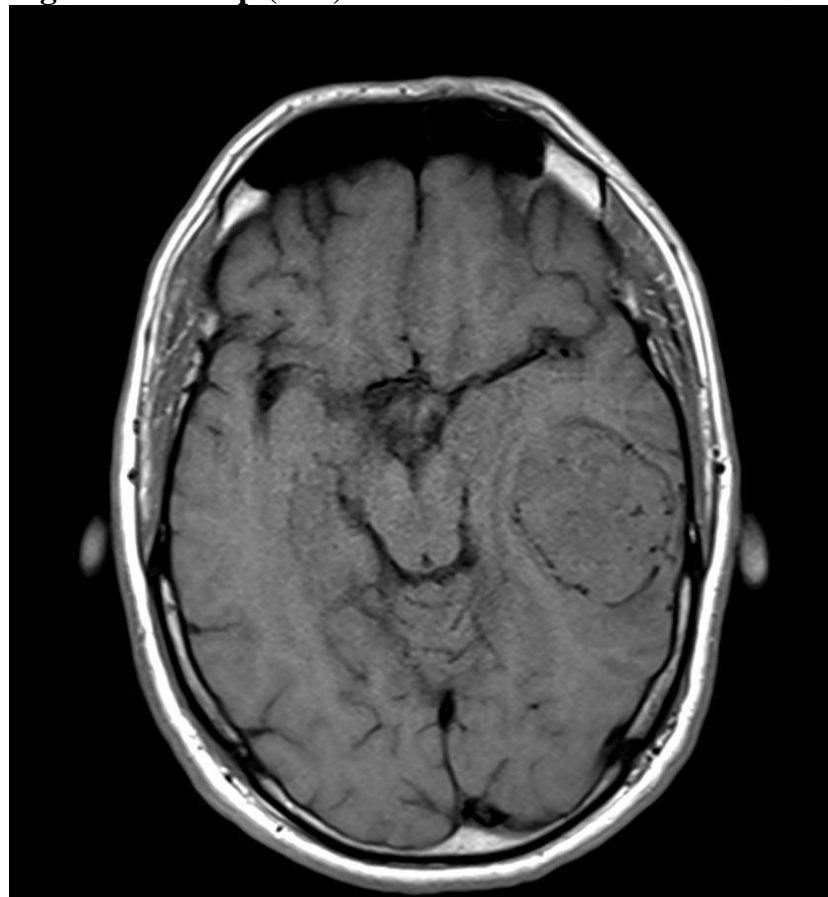

Figure 1. Preop (TM) T1 coronal MR (+C)

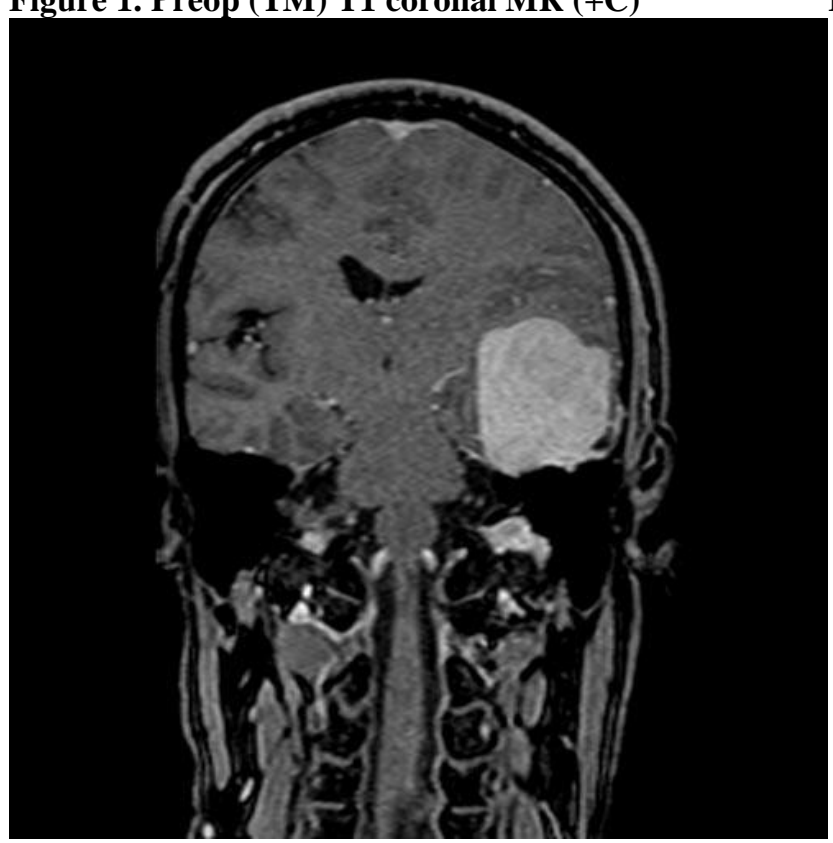

En bloc resection was performed and pathological examination revealed an HPC (WHO grade 2) that did not contain anaplastic cells. Cranial computed tomography (CT) was carried out on the 5th postoperative day and nothing was seen except for postoperative changes (Figure-2). Postoperative RT was not performed, and in the 3rd postoperative month, the patient complained of dizziness.

Although the patient's neurological exam was intact, cranial MR imaging (MRI) was performed for
Figure 1b. Preop (TM) T2 coronal MR

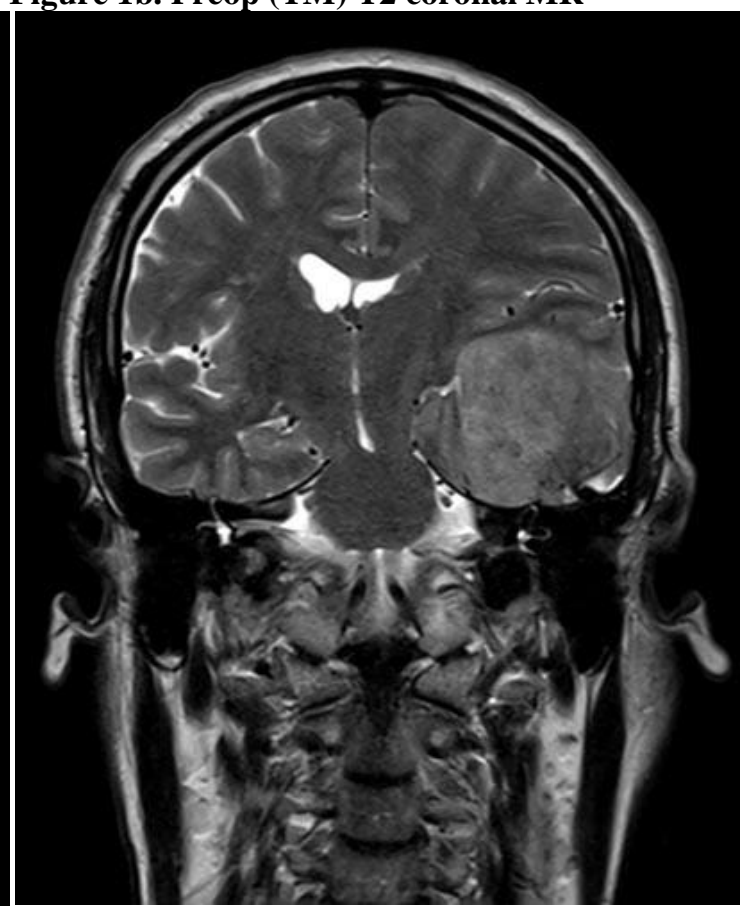

Figure 1d. Preop (TM) T1 sagittal MR (+C)

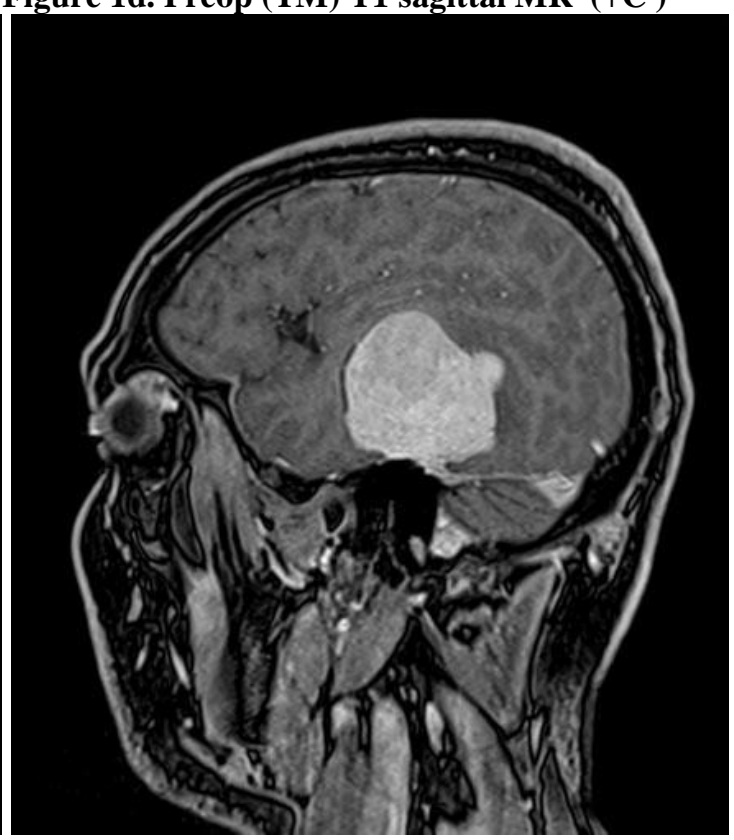

verification. In the control cranial MR, there was a mass lesion that was highlighted in the MR report as a recurrent tumor (Figure-3a; 3b; 3c; 3d). Thus, the patient underwent a second operation.

In this operation, we saw a huge coagulated hematoma that filled the entire tumor space. This was emptied and pathology verified that it was a hematoma. On the 2 nd postoperative day, cranial CT was found to be normal (Figure-4) and the patient was discharged on the 5th postoperative day. 
Figure 3a. Preop ( HEM ) T1 axial MR

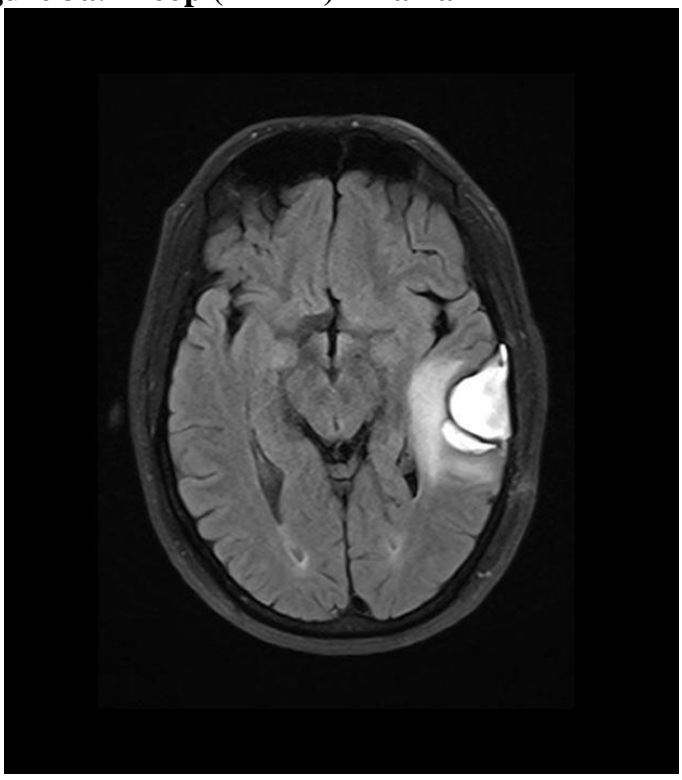

Figure 3c. Preop (HEM) T1 coronal MR (+C)

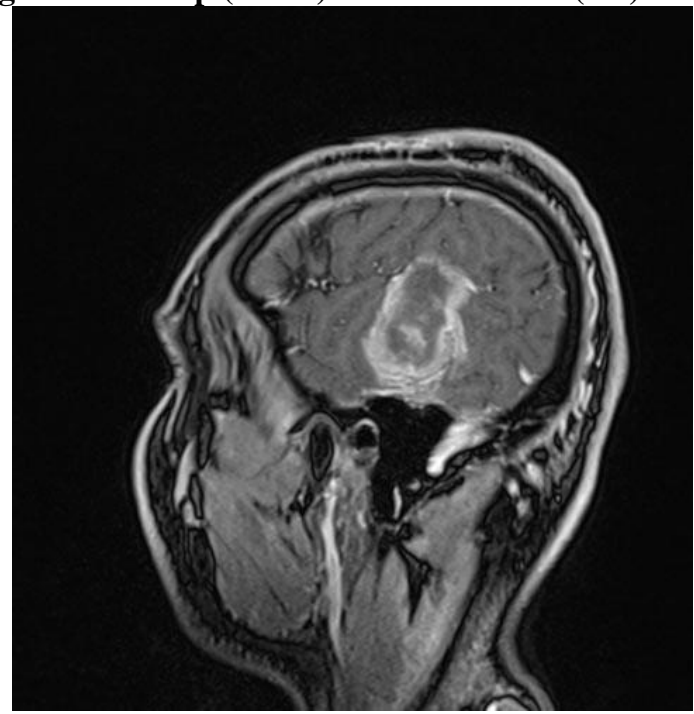

Figure 3b. Preop ( HEM ) T2 coronal MR

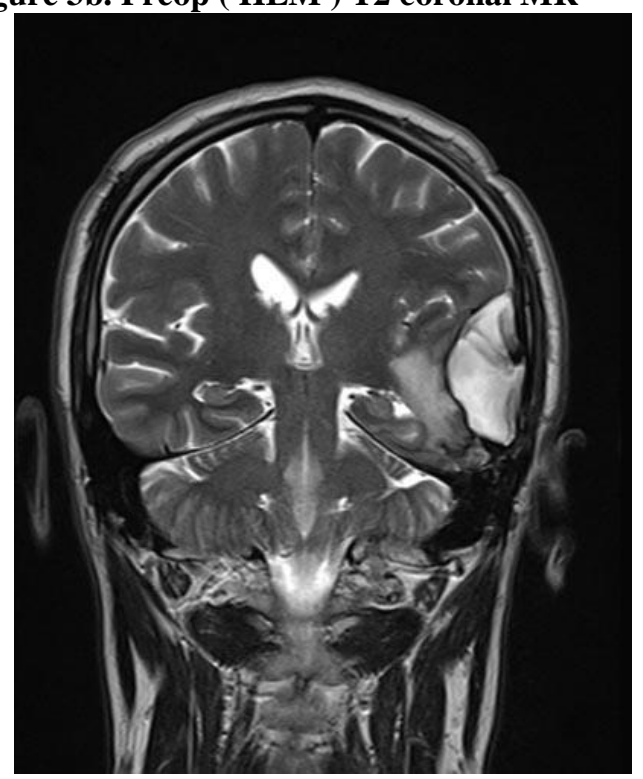

Figure 3d. Preop (HEM) T1 sagittal MR (+C)

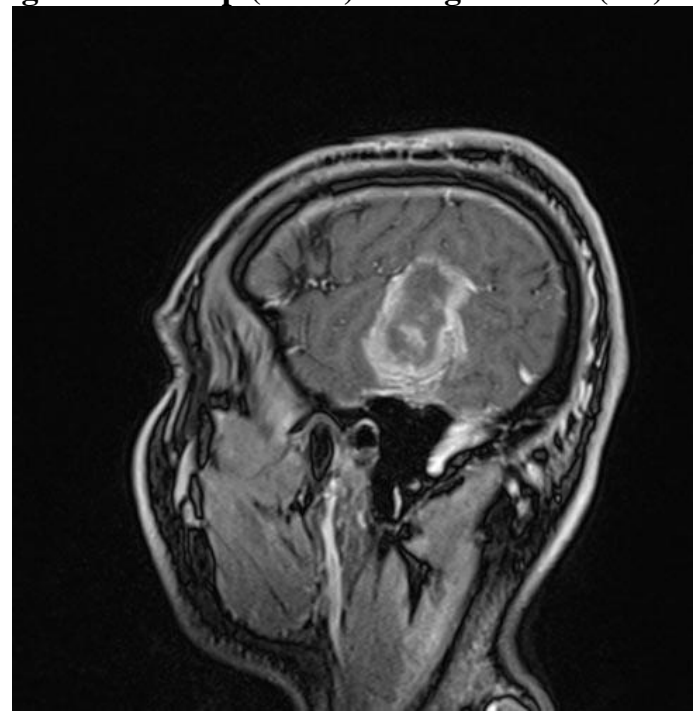

Figure 4. Postop ( HEM ) BT

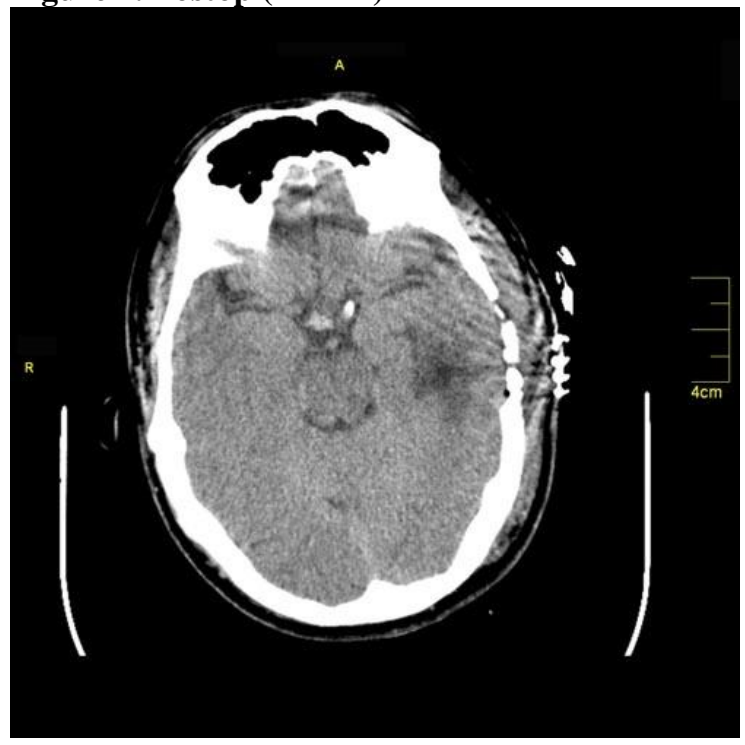




\section{DISCUSSION}

Meningeal HPCs are rare, aggressive, mesenchymal tumors that constitute $0.4 \%$ of all central nervous system tumors (9). Twenty-five percent of HPCs occur in the cranial and cervical region and their etiology is unknown. Histologically, they are cellular and vascular tumors. They develop from malignant transformation of pericytes, which comprise the walls of capillaries and post-capillary venules.

Cephalgia was found the most common complaint in Goellner et al.`s series (3).

HPCs are seen as heterogeneous, hyperdense lesions on non-contrast cranial CT and do not contain calcifications, distinct from meningiomas. Moreover, they do not result in hyperostosis in the neighboring calvarium(4).

An HPC under MRI is visualized as heterogeneous and isointense on T1- and T2-weighted images; in addition, it contains obvious internal vascular void. Moreover, the contrast is enhanced in contrasted slices. The dural tail sign was seen in half of the cases in Chiechi et al.'s series (1); while dural attachment is broad on CT and MR in cases of meningioma, HPC must be considered if this attachment is narrow.

Despite sharing the arachnoid locations of meningiomas, HPCs are distinguished by their more aggressive biology, appearance at young age and higher possibility of recurrence and extracranial metastasis (6). HPCs are defined surgically well demarcated, attached to the dura mater and mostly exhibit hemorrhagic lesions $(3,4)$. While HPC is categorized as grade 2 in the WHO classification, its anaplastic form is considered grade 3 (5).

As HPCs are mostly vascularized tumors, they have a tendency to bleed. One HPC case in the literature presented with acute intracerebral hemorrhage (2). The local recurrence rate is $57 \%$, and metastasis was seen $27 \%$ in the latest series of 277 HPC cases (8). Tumor size and location have also been found to be related with the possibility of recurrence (7). Specifically, HPCs greater than $6 \mathrm{~cm}$ recur earlier $(2.1$ years) than those smaller than $6 \mathrm{~cm}$ (10.1 years). When anatomic locations are analyzed, HPCs that are not localized at the skull base recur in 3.9 years, whereas skull baseoriginated HPCs recur after 9.3 years.

Besides gross total resection, RT is advised in cases of anaplastic HPC (WHO grade 3) and partially resected WHO grade 2 or operative cases (2). In light of the literature findings, we did not apply additional therapy except en bloc resection.

Hematoma appearing after three months postoperatively made us to think recurrence minimally in spite of the MR report and the lack of RT. We thought the possibility of recurrence was not high because the HPC was located at the skull base, the mass was smaller than $6 \mathrm{~cm}$ and we had performed en bloc resection in our case.

\section{CONCLUSION}

Postoperative RT is not necessary in WHO grade 2 HPCs. While interpreting postoperative complications of these tumors, their aggressiveness, the likelihood of treatment failure, and the results of the MR report should be kept in mind as well as the tumor's size, location, and vascular characteristics.

\section{REFERENCES}

1. Chiechi MV, Smirniotopoulos JG, Mena H. Intracranial Hemangiopericytomas: $\mathrm{MR}$ and $\mathrm{CT}$ Features. Am J Neuroradiol 1996;17:1365-1371.

2. Fredriksson F, Nordborg C, Hallén T, Blomquist E. Haemangiopericytoma presenting with acute intracerebral haemorrhage-a case report and literature review. Acta Oncol 2013;52(4):753-758.

3. Goellner JR, Laws ER, Soule EH, Okazaki H. Hemangiopericytoma of the meninges: Mayo Clinic experience. Am J Clin Pathol 1978;70:375-380.

4. Jaaskelainen J, Servo A, Haltia M, Wahlstrom T, Valtonen S. Intracranial hemangiopericytoma: radiology, surgery, radiotherapy, and outcome in 21 patients. Surg Neurol 1985;23:227-236.

5. Louis DN, Wiestler OD, Cavenee WK, eds. WHO Classification of Tumours of the Central Nervous System. Lyon, France: IARC Press; 2007;178-180.

6. Mena H, Ribas JL, Pezeshkpour GH, Cowan DN, Parisi JE. Hemangiopericytoma of the central nervous system: a review of 94 cases. Hum Pathol 1991;22:84-89.

7. Rutkowski MJ, Jian BJ, Bloch O, Chen C, Sughrue ME, Tihan T,et al. Intracranial hemangiopericytoma: clinical experience and treatment considerations in a modern series of 40 adult patients. Cancer 2012; $15 ; 118(6): 1628-1636$.

8. Rutkowski MJ, Sughrue ME, Kane AJ, Aranda D,Mills SA, Barani IJ, et al. Predictors of mortality following treatment of intracranial hemangiopericytoma. J Neurosurg 2010;113:333339.

9. Schiariti M, Goetz P, El-Maghraby H, Tailor J, Kitchen N: Hemangiopericytoma: long-term outcome revisited. Clinical article. J Neurosurg 2010;114:747-755. 